\title{
Influence of Gypsum Waste Utilization on Properties and Leachability of Fired Clay Brick
}

\author{
Nur Jannah Abdul Hamid ${ }^{1}$, Aeslina Abdul Kadir ${ }^{1,2,3, *}$, Nurul Nabila Huda Hashar ${ }^{1}{ }^{(D}$, Paweł Pietrusiewicz $^{4} \mathbb{D}^{(}$,

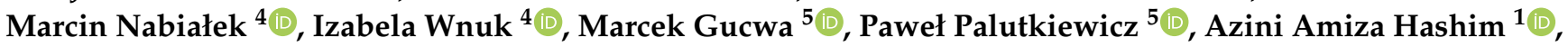 \\ Noor Amira Sarani ${ }^{1}$, Amos Anak Nio ${ }^{1}$, Norazian Mohamed Noor ${ }^{3}$ and Bartłomiej Jez ${ }^{4}$
}

1 Department of Water and Environmental Engineering, Faculty of Civil Engineering and Built Environment, Universiti Tun Hussein Onn Malaysia, Parit Raja 86400, Batu Pahat, Johor, Malaysia; jannahamid93@gmail.com (N.J.A.H.); nurulnabilahudahashar@gmail.com (N.N.H.H.); aziniamizaa@gmail.com (A.A.H.); nramira1987@gmail.com (N.A.S.); amosanaknio@gmail.com (A.A.N.)

2 Micropollutant Research Centre (MPRC), Universiti Tun Hussein Onn Malaysia, Parit Raja 86400, Batu Pahat, Johor, Malaysia

3 Center of Excellence Geopolymer and Green Technology (CEGeoGTech), University Malaysia Perlis, Arau 02600, Perlis, Malaysia; norazian@unimap.edu.my

4 Department of Physics, Częstochowa University of Technology, 42-201 Częstochowa, Poland; pawel.pietrusiewicz@pcz.pl (P.P.); nmarcell@wp.pl (M.N.); izabela.wnuk@pcz.pl (I.W.); bartek199.91@o2.pl (B.J.)

5 Department of Technology and Automation, Faculty of Mechanical Engineering and Computer Science, Częstochowa University of Technology, 42-201 Częstochowa, Poland; mgucwa@spaw.pcz.pl (M.G.); palutkiewicz@ipp.pcz.pl (P.P.)

check for updates

Citation: Hamid, N.J.A.; Kadir, A.A.; Hashar, N.N.H.; Pietrusiewicz, P.; Nabiałek, M.; Wnuk, I.; Gucwa, M.; Palutkiewicz, P.; Hashim, A.A.; Sarani, N.A.; et al. Influence of Gypsum Waste Utilization on Properties and Leachability of Fired Clay Brick. Materials 2021, 14, 2800. https://doi.org/10.3390/ma14112800

Academic Editor: Rui Miguel Novais

Received: 22 March 2021

Accepted: 9 May 2021

Published: 24 May 2021

Publisher's Note: MDPI stays neutral with regard to jurisdictional claims in published maps and institutional affiliations.

Copyright: (c) 2021 by the authors. Licensee MDPI, Basel, Switzerland. This article is an open access article distributed under the terms and conditions of the Creative Commons Attribution (CC BY) license (https:// creativecommons.org/licenses/by/ $4.0 /)$.
* Correspondence: aeslina@uthm.edu.my

\begin{abstract}
Wastewater treatment activities in the chemical industry have generated abundant gypsum waste, classified as scheduled waste (SW205) under the Environmental Quality Regulations 2005. The waste needs to be disposed into a secure landfill due to the high heavy metals content which is becoming a threat to the environment. Hence, an alternative disposal method was evaluated by recycling the waste into fired clay brick. The brick samples were incorporated with different percentages of gypsum waste $(0 \%$ as control, 10, 20, 30, 40 and $50 \%)$ and were fired at $1050{ }^{\circ} \mathrm{C}$ using $1{ }^{\circ} \mathrm{C}$ per minute heating rate. Shrinkage, dry density, initial rate of suction (IRS) and compressive strength tests were conducted to determine the physical and mechanical properties of the brick, while the synthetic precipitation leaching procedure (SPLP) was performed to scrutinize the leachability of heavy metals from the crushed brick samples. The results showed that the properties would decrease through the incorporation of gypsum waste and indicated the best result at $10 \%$ of waste utilization with $47.5 \%$ of shrinkage, $1.37 \%$ of dry density, $22.87 \%$ of IRS and $28.3 \%$ of compressive strength. In addition, the leachability test highlighted that the concentrations of $\mathrm{Fe}$ and $\mathrm{Al}$ was significantly reduced up to $100 \%$ from 4884 to $3.13 \mathrm{ppm}(\mathrm{Fe})$ and from 16,134 to $0.81 \mathrm{ppm}(\mathrm{Al})$, respectively. The heavy metals content in the bricks were oxidized during the firing process, which signified the successful remediation of heavy metals in the samples. Based on the permissible incorporation of gypsum waste into fired clay brick, this study promised a more green disposing method for gypsum waste, and insight as a potential towards achieving a sustainable end product.
\end{abstract}

Keywords: fired clay brick; gypsum waste; properties; leaching test; synthetic precipitation leaching procedure

\section{Introduction}

Waste is defined as the substance prescribed to be the scheduled waste or any other matter in the form of a solid, semi-solid, liquid, vapor, or gas [1]. Additionally, it could be emitted, discharged or deposited onto the environment in such a volume, composition or manner to cause pollution. In Malaysia, 1.6 million metric tons of industrial sludge is 
produced annually, while 0.81 million metric tons are disposed at sanitary landfills [1]. Scheduled wastes are the categories of waste listed under the First Schedule of Environmental Quality Regulations 2005 [2]. The categories of the scheduled waste are classified as environmental hazardous waste due to the toxic and high-risk nature of a particular type of waste. Gypsum waste that arose from the chemical industry was classified as the waste containing principally inorganic constituents, which may comprise metals and organic materials.

Gypsum waste becomes a very serious environmental issue as the common disposal methods applied involve landfilling and burning in the incinerator. This situation affects people's health and sanitary issues. Gypsum waste was banned from being disposed in a normal landfill as it was mixed with other biodegradable waste which led to hydrogen sulfide gas emission through microbial action [3]. In addition, hydrogen sulfide is toxic, colorless and flammable and has distinct foul odor of rotten eggs that could cause breathing difficulties, discoloration of the skin and eye irritation [4]. Nevertheless, the current limited landfill has urged the search for an alternative disposal method since the existing landfills can no longer accommodate the disposal of gypsum waste.

Recently, various measures have been carried out to create more environmentally friendly and economic products with similar original resilience $[5,6]$. The products will be embedded with residual waste from industry or residential waste. Therefore, the incorporation of gypsum waste into fired clay brick is an attempt to save the space for landfill, the cost of disposal management as well the environment [7]. Simultaneously, the rapid growth in the construction sector has led to the demand for building materials such as fired clay bricks due to its properties. Hence, this study was conducted to investigate the properties and leaching behavior of fired clay bricks incorporated into gypsum waste. Besides, this study also focused on both properties and leachability where most previous studies only discussed the properties of a particular product.

\section{Materials and Methods}

\subsection{Raw Materials and Their Preparation}

In this study, gypsum waste was obtained from a chemical industry located in Johor Bahru, Johor, Malaysia. The gypsum waste was in sludge form, as shown in Figure 1, while the clay soil was collected from a quarry in Batu Pahat, Johor. Both of the raw materials were dried in the oven (Memmert, $+300{ }^{\circ} \mathrm{C}$, Schwabach, Germany) at $105{ }^{\circ} \mathrm{C}$ for $24 \mathrm{~h}$ to remove the water content before being ground in order to obtain the uniform size of the particles to yield a homogeneous mixture of brick. The gypsum waste and clay soil were kept in a closed container to avoid any contaminants getting into them before being used.

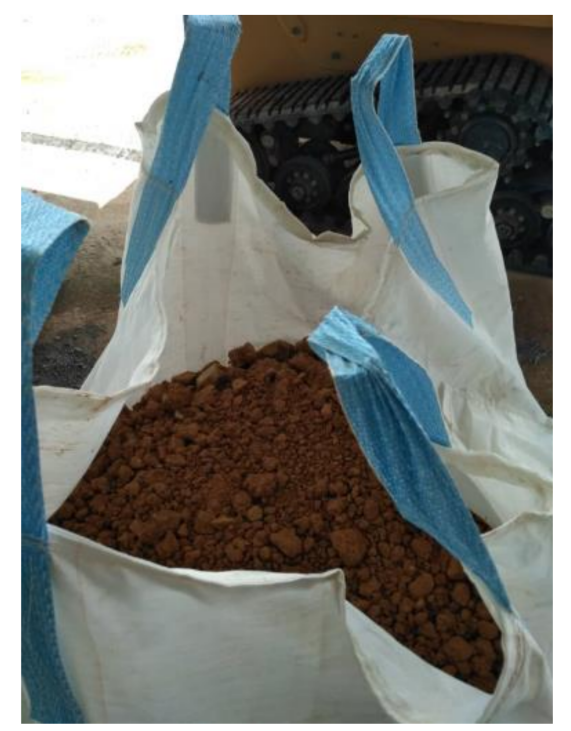

Figure 1. Gypsum waste from chemical industry. 


\subsection{Chemical and Geotechnical Properties}

The chemical characterization of the raw materials was determined by using X-ray fluorescence (XRF, Philips, PW1840, Malvern, UK). Geotechnical properties of the raw materials used were determined by conducting the Atterberg Limit test, specific gravity test and standard proctor test. The Atterberg Limit and specific gravity were investigated in accordance the BS-1377-2 [8] and the standard proctor test was based on BS-1377-4 [9]. The optimum moisture content for control brick and clay-gypsum waste bricks was determined to produce a good quality of brick.

\subsection{Methods Used for Brick Samples Preparation}

There were two types of bricks manufactured which consist of control bricks and claygypsum waste bricks. The control brick contained $100 \%$ clay soil without gypsum waste incorporation, while the clay-gypsum waste brick was designed with different gypsum waste content (10,20,30, 40 and 50\%), as shown in Table 1 . The processes to manufacture the brick samples was started by mixing the clay soil and gypsum waste with a predetermined amount of water using a mechanical mixer with a $10 \mathrm{~L}$ capacity (Hobart Mechanical Mixer, South Ridge Ave., Troy, OH, USA). After the mixture was homogeneously prepared, the samples were put into a mold with the dimension of $215 \mathrm{~mm} \times 102.5 \mathrm{~mm} \times 65 \mathrm{~mm}$ and were compacted at the pressure of 2000 psi (Eco Global Technology, Brick machine, Johor Bahru, Malaysia). Then, the samples were dried at room temperature for $24 \mathrm{~h}$ with another $24 \mathrm{~h}$ in the oven at the temperature of $105^{\circ} \mathrm{C}$ [10]. The drying process was carried out subsequently to prevent disintegration due to the rapid loss of moisture content within the brick samples.

Table 1. Design of mixtures for manufactured fired clay brick.

\begin{tabular}{|c|c|c|c|c|c|c|}
\hline Sample & $\begin{array}{c}\text { Gypsum Waste } \\
(\%)\end{array}$ & $\begin{array}{c}\text { Clay Soil } \\
(\%)\end{array}$ & $\begin{array}{c}\text { Gypsum Waste } \\
(\mathrm{kg})\end{array}$ & $\begin{array}{c}\text { Clay Soil } \\
\text { (kg) }\end{array}$ & $\begin{array}{l}\text { Total Mass } \\
\text { (kg) }\end{array}$ & $\begin{array}{c}\text { Water } \\
(\mathrm{mL})\end{array}$ \\
\hline \multirow[t]{3}{*}{ Control brick } & 0 & 100 & 0.00 & 2.80 & 2.80 & 475 \\
\hline & 10 & 90 & 0.20 & 2.60 & 2.80 & 515 \\
\hline & 20 & 80 & 0.47 & 2.33 & 2.80 & 550 \\
\hline \multirow[t]{3}{*}{ Gypsum brick } & 30 & 70 & 0.81 & 1.99 & 2.80 & 585 \\
\hline & 40 & 60 & 1.25 & 1.55 & 2.80 & 650 \\
\hline & 50 & 50 & 1.88 & 0.92 & 2.80 & 695 \\
\hline
\end{tabular}

Next, as shown in Figure 2, by using the heating rate of $1{ }^{\circ} \mathrm{C} / \mathrm{min}$, the samples were gradually fired in the furnace up to a firing temperature of $1050^{\circ} \mathrm{C}$ for two hours [11]. The selected firing temperature and heating rate were closely related to the current practice in the brick industry. Besides that, the exemplary firing temperature reported in a few studies indicated that $1050^{\circ} \mathrm{C}$ could achieve the vitrification phase at an optimal level which contributed to the better particle bonding, leading to the high strength of brick samples produced [12-14]. Thereafter, all brick samples were tested for physical and mechanical properties including shrinkage, dry density, initial rate of suction (IRS) [15] and compressive strength according to the British Standard (BS 3921: 1985) [16].

The leaching behavior of the brick samples was tested according to the synthetic precipitation leaching procedure (SPLP) to determine the concentration of heavy metals as, described in Method 1312 [17]. The leaching test was conducted to not exceed the regulatory threshold limit set by the United State Environment Protection Agency. The SPLP was designed to stimulate the condition of brick samples when being exposed to acid rain.

The samples were prepared in a screw-capped polyethylene bottles which were filled with crushed samples and leaching fluid at the ratio of 1:20. The particle size was required to pass through $9.5 \mathrm{~mm}$ standard sieve and the extraction fluid employed was a $\mathrm{pH} 4.2$ solution consisted of sulfuric acid/nitric acid $\left(\mathrm{H}_{2} \mathrm{SO}_{4} / \mathrm{HNO}_{3}\right)$, which were mixed carefully. The bottles were rotated by using a rotary agitation holder for about $18 \mathrm{~h}$ at $30 \mathrm{rpm}$. 
Then, the mix underwent the infiltration process using $0.7 \mu \mathrm{m}$ glass fiber filters (Whatman, Maidstone, Kent, UK) to filter rough residues before being analyzed with inductive coupled plasma mass spectrometry (ICP-MS, PerkinElmer Elan9000, Shelton, CT, USA). The results obtained were compared to the United States Environmental Protection Agency (USEPA) standard [17].

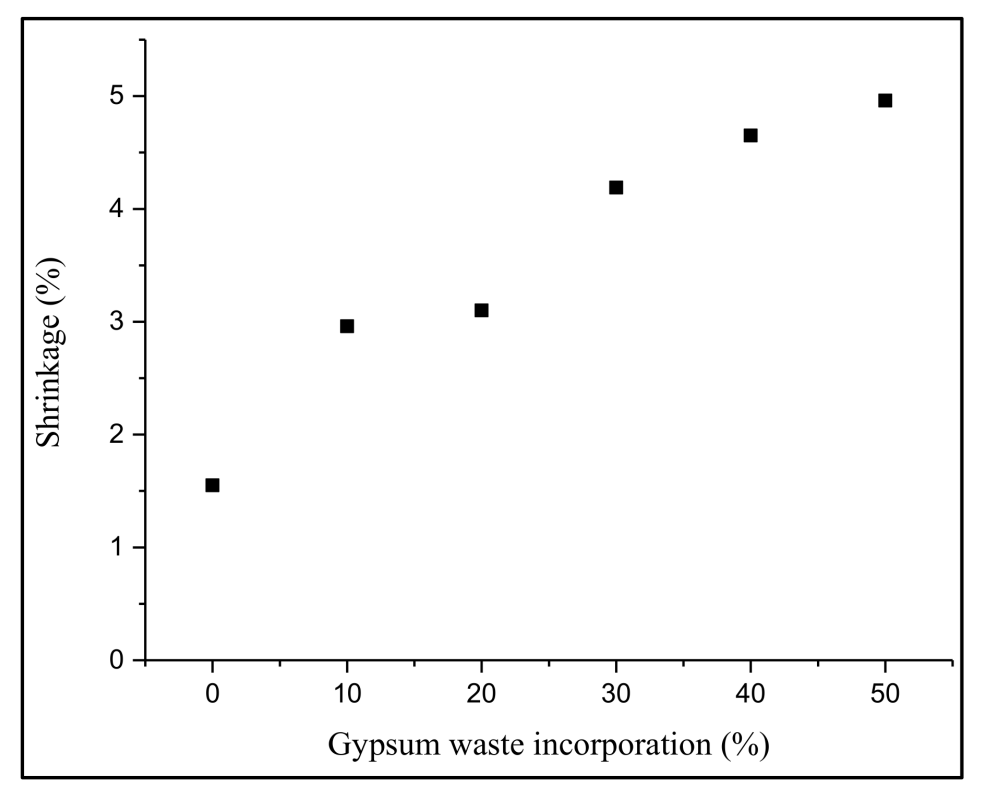

Figure 2. Effect of gypsum waste utilization on the shrinkage of fired clay brick.

\section{Results and Discussion}

\subsection{Properties of Raw Materials}

X-ray fluorescence (XRF) was used to determine the main composition of the raw materials used, which were clay and gypsum waste, as shown in Table 2. The highest element contents in the clay soil were $\mathrm{SiO}_{2}$ and $\mathrm{Al}_{2} \mathrm{O}_{3}$ with $40.8 \%$ and $38.70 \%$, respectively, while $\mathrm{CaO}$ had the lowest concentration, which was only $0.10 \%$. The results were consistent with previous studies that showed the high composition of silica and alumina in raw materials can enhance the refractoriness of the bricks, thus, improved the mechanical properties as well $[18,19]$. Meanwhile, for gypsum waste, the highest concentration were $\mathrm{CaO}$ and $\mathrm{SO}_{3}$ at $29.57 \%$ and $29.56 \%$, respectively. Concurrently, the valuable components of calcium sulfate in gypsum had the potential to be used as the binder for waste sludge treatment. The presence of $\mathrm{CaO}, \mathrm{MgO}$ and $\mathrm{Na}_{2} \mathrm{O}$ in gypsum waste were higher than in the clay soil were reported as fluxing agents that can decrease the firing temperature, hence, lowering the energy consumption used during firing stage [20,21]. Moreover, the amount of $\mathrm{Fe}_{2} \mathrm{O}_{3}$ in both of the raw materials were quite similar, where it resembled the reddish color of bricks after the firing process.

The geotechnical properties of the clay soil were tabulated as in Table 3. The liquid limit and plasticity for the clay soil was $29.3 \%$ and $13.1 \%$, respectively. In order to produce a good quality and fair properties of bricks, the limit value for the plastic limit value was required to be in the range of 12 to $22 \%$, while for the plasticity index, the range was 7 to $18 \%$, as recommended in the associated literature on small-scale brickmaking [22]. Clay soil, that has a well-known flexibility to bind with another material, could be a great potential in producing clay-gypsum waste brick with a medium degree of plasticity and being classified as silt clay in this study [23]. 
Table 2. XRF of clay soil and gypsum waste.

\begin{tabular}{cccc}
\hline & & \multicolumn{2}{c}{ Concentration (wt\%) } \\
\cline { 3 - 4 } No & & Clay Soil & Gypsum Waste \\
\cline { 3 - 4 } & $\mathrm{CaO}$ & 0.10 & 29.57 \\
2 & $\mathrm{SO}_{3}$ & 0.27 & 29.56 \\
3 & $\mathrm{Al}_{2} \mathrm{O}_{3}$ & 38.70 & 16.13 \\
4 & $\mathrm{SiO}_{2}$ & 40.8 & 8.86 \\
5 & $\mathrm{MgO}$ & 0.36 & 7.82 \\
6 & $\mathrm{Fe}_{2} \mathrm{O}_{3}$ & 5.41 & 4.88 \\
7 & $\mathrm{Na}_{2} \mathrm{O}$ & 0.47 & 2.39 \\
8 & $\mathrm{P}_{2} \mathrm{O}_{5}$ & - & 0.39 \\
9 & $\mathrm{MnO}$ & - & 0.15 \\
10 & $\mathrm{~K}_{2} \mathrm{O}$ & 0.22 & 0.11 \\
11 & $\mathrm{Cl}$ & - & $418.00 \mathrm{mg} / \mathrm{kg}$ \\
12 & $\mathrm{TiO}_{2}$ & 1.05 & $344.00 \mathrm{mg} / \mathrm{kg}$ \\
13 & $\mathrm{ZnO}_{10}$ & - & $111.00 \mathrm{mg} / \mathrm{kg}$ \\
14 & $\mathrm{Cr}_{2} \mathrm{O}_{3}$ & - & $56.00 \mathrm{mg} / \mathrm{kg}$ \\
\hline
\end{tabular}

Table 3. Geotechnical properties.

\begin{tabular}{cc}
\hline Properties & Clay Soil \\
\hline Specific gravity & 2.6 (clay soil), 2.5 (gypsum waste) \\
Liquid limit (\%) & 29.3 \\
Plastic limit (\%) & 16.2 \\
Plasticity index (\%) & 13.1 \\
Degree of plasticity & Medium Plastic \\
Type of soil & Silty clay or clayey silt \\
\hline
\end{tabular}

\subsection{Shrinkage of Manufactured Bricks}

Shrinkage occurs when the loss of capillary water during the drying and firing processes causes contraction in the hardened mixture. The factors that influenced the amount of shrinkage were basically the characteristics of the materials mixed, the proportion of the mixture, manufacturing processes, moisture content and dry condition applied [24]. The shrinkage of manufactured fired clay brick samples is presented in Figure 2. The results showed that the samples with $50 \%$ gypsum waste incorporation had the highest value of shrinkage with $4.96 \%$, followed by samples with $40 \%$ gypsum with the value of $4.65 \%$. This showed that by increasing the percentage of gypsum waste incorporation, the shrinkage of the fired clay brick would increase. The $10 \%$ gypsum waste utilization demonstrated $47.5 \%$ shrinkage of the control brick value. The similar trend of the results was also recorded in a previous study which incorporated waste sludge into clay bricks. The study reported that the least amount of shrinkage must be below $8 \%$ to be regarded as a good quality of bricks [25]. Moreover, the shrinkage value of gypsum brick was higher due to water demand during the mixing process, which was more compared to the control brick. Although the shrinkage value increased, the gypsum brick still complied with the preferable shrinkage properties up to $20 \%$ with the value of $3.1 \%$ [26]. Additionally, the drying and firing stage had caused the loss of water particles in the bricks and affected the shrinkage behaviors relatively [27].

\subsection{Dry Density of Manufactured Bricks}

Based on Figure 3, the dry density of the fired clay brick manufactured varies from 1830 to $1216 \mathrm{~kg} / \mathrm{m}^{3}$ in different percentages. The $10,20,30$ and $40 \%$ gypsum brick recorded 1805 , 1711,1672 and $1429 \mathrm{~kg} / \mathrm{m}^{3}$ of dry density values, respectively, which decreased gradually with the increase in gypsum waste incorporation. The same results were reported where the weight of the bricks was reduced when the waste content was increased [28,29]. Meanwhile, the control brick had the highest dry density with $1830 \mathrm{~kg} / \mathrm{m}^{3}$ whilst the lowest density 
was $50 \%$ of gypsum brick with the value of $1216 \mathrm{~kg} / \mathrm{m}^{3}$. The particle density of the bricks decreased when the sludge waste was added proportionally, which is supported by [28,29]. This trend related to the specific gravity (SG) value of the clay soil, which was higher than gypsum waste and had affected the density of the bricks since more water was absorbed into the larger pores within the brick bodies. Therefore, a lightweight brick was produced with the increasing gypsum waste content. Moreover, the gypsum waste tended to get burnt away during the firing process due to high temperature exposure, consequently creating pores [30]. Although gypsum bricks had a lower dry density than the control brick, the density values still indicated that all the samples complied with the standard density requirement. According to [30], gypsum has the potential to bind soil particles and could enhance the strength of soil mixtures, especially in a dry environment. Despite the nature of gypsum which was soluble in water, the firing process helped in removing three-quarters of the water molecules by evaporation and the formation of stable elements encapsulated in the bricks.

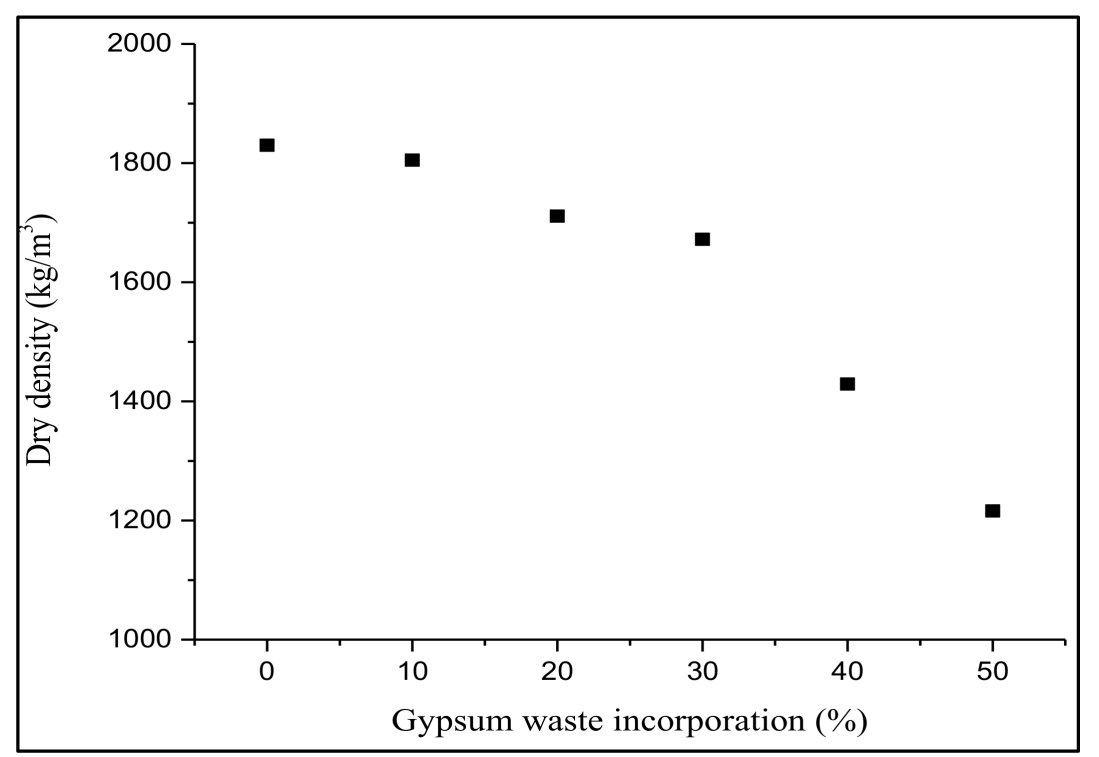

Figure 3. Effect of gypsum waste utilization on the dry density of fired clay brick.

\subsection{Initial Rate of Suction (IRS) of Manufactured Bricks}

The initial rate of suction (IRS) value represents the ability and the potential performance of the brick in laying and durability. Based on Figure 4, the control brick showed the lowest value of IRS compared to the gypsum brick with the value of $2.9 \mathrm{~kg} / \mathrm{m}^{2} . \mathrm{min}$. The highest IRS value was from the $50 \%$ gypsum brick with $11.81 \mathrm{~kg} / \mathrm{m}^{2} . \mathrm{min}$ and followed by the 40, 30, 20 and 10\% gypsum brick with value of IRS at 9.39, 7.48, 5.83 and $3.76 \mathrm{~kg} / \mathrm{m}^{2}$.min, respectively. The results indicated that the IRS values increased when the percentages of gypsum waste increased due to the interconnected pores, voids and capillaries that appeared in the bricks. The results recorded a similar trend in the previous study which supported the suction rate was increased as the waste content increased [31]. According to BS EN 771-1 [32]. the value of IRS should be lower than $2 \mathrm{~kg} / \mathrm{m}^{2}$.min, but unfortunately, all the bricks showed higher values which were more than the acceptable limit. Gypsum bricks showed the highest value of IRS as gypsum waste was prone to be burnt away during the firing process due to the high temperature, hence resulting in pore development in the brick. Bricks with high porosity tended to absorb more water compared to the brick with low porosity and could lead to volume changes and cause cracking to the bodies of the bricks [33]. Since there is limited specific guidance for IRS requirements, the gypsum brick could still be useful in construction works but must be wetted earlier from three hours to $24 \mathrm{~h}$ before being laid [34]. 


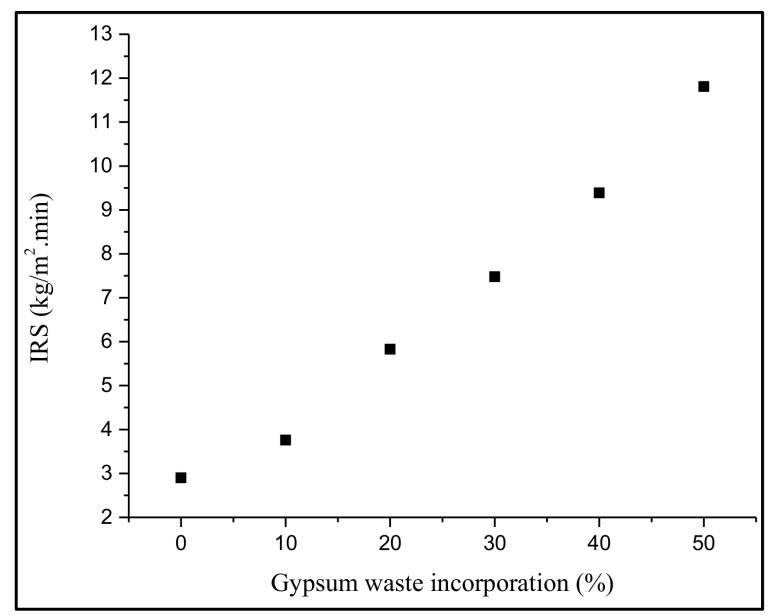

Figure 4. Effect of gypsum waste utilization on the initial rate of suction of fired clay brick.

\subsection{Compressive Strength of Manufactured Bricks}

According to Figure 5, the results showed that the highest compressive strength was achieved by the control brick with $25.8 \mathrm{MPa}$, followed by the 10 and $20 \%$ gypsum brick at 18.5 and $10.9 \mathrm{MPa}$, respectively. In addition, the 30,40 and $50 \%$ gypsum bricks with the values of $4.3,1.9$ and $0.8 \mathrm{MPa}$, respectively, did not comply with the standard of BS 3921: 1985 where the minimum requirement of compressive strength of the brick should not be less than 7.0 MPa. The compressive strength of the gypsum brick was lower due to the high porosity and high IRS value compared to control bricks [35]. Based on the results, the increasing amount of gypsum waste incorporation into fired clay brick lowered the density of the gypsum bricks, consequently decreasing the compressive strength. Additionally, a previous study investigated showed that a weak inter-particulate within the manufactured brick occurred when the clay soil burnt during the firing process [36]. Besides that, the previous study claimed the same trend that the disintegration of the particles in the bricks during the firing stage had weakened the clay-waste composite caused by the presence of pores [37]. Apart from that, for gypsum brick with 10 and $20 \%$ gypsum waste incorporation fulfilled the requirement for the non-load bearing applications, which should not be less than $5 \mathrm{~N} / \mathrm{mm}^{2}$ according to BS 3921:1985.

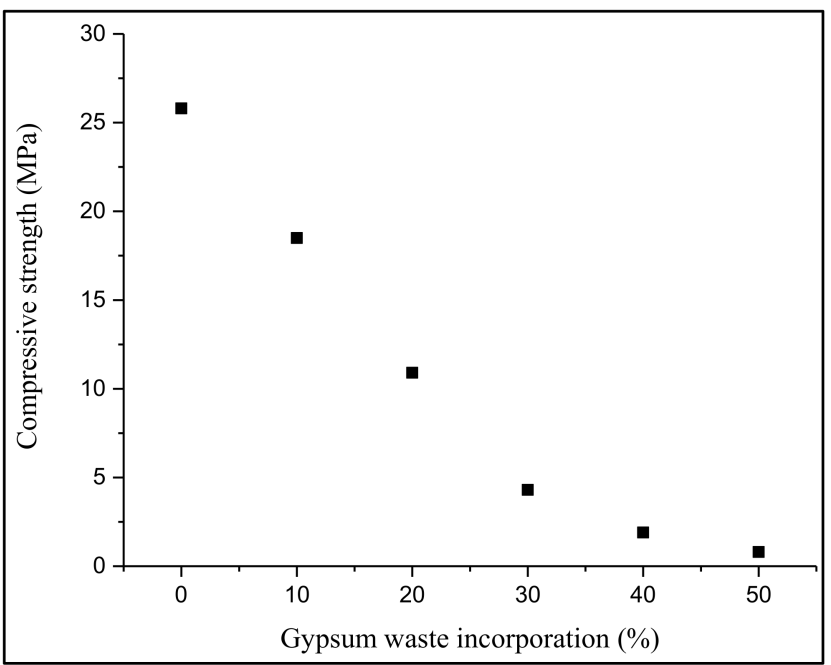

Figure 5. Effect of gypsum waste utilization on the compressive strength of fired clay brick.

\subsection{Leachability of Fired Clay Brick}

The leachability of heavy metals in the samples was carried out on crushed samples for short-term testing and the results are presented in Table 4 . The highest concentration of 
heavy metal in gypsum brick was iron (Fe) with 3.13, 3.61, 3.66, 3.83 and $3.85 \mathrm{ppm}$ for 10, $20,30,40$ and $50 \%$, respectively. The Fe concentration in the gypsum brick also showed a huge difference compared to the control brick, which was $0.033 \mathrm{ppm}$, which represented the permeability and durability of bricks [38]. Meanwhile, the highest concentration of aluminum (Al) was showed in the gypsum brick at $50 \%$ with $1.91 \mathrm{ppm}$ followed by the gypsum brick at $40 \%$ with $1.88 \mathrm{ppm}$. The results were consistent with the studies conducted previously that stated during the firing process, the heavy metals were oxidized, which reduced the level of the toxicity in the bricks [38]. In addition, the immobilization of heavy metals occurred at a high firing temperature [39,40]. However, all the heavy metals were in reliance and the gypsum bricks were complied with the standard concentration limits. From the SPLP results, the $\mathrm{pH}$ of leachate mixture was considered as one of the factors that contributed to the lower heavy metals amount in the leachate, as shown in Figure 6. The values were below the USEPA standard; thus, the incorporation of gypsum waste into fired clay brick could be an alternative to reutilize the gypsum waste in fired clay brick. Furthermore, the utilization of gypsum as a building material is gaining more attention as it is one of the most environmentally friendly binders [41].

Table 4. Heavy metals in fired clay brick samples by using SPLP.

\begin{tabular}{|c|c|c|c|c|c|c|c|}
\hline \multirow{3}{*}{ Heavy Metals } & \multicolumn{6}{|c|}{ Concentration (ppm) } & \multirow{3}{*}{ USEPA } \\
\hline & \multirow{2}{*}{ Control Brick } & \multicolumn{5}{|c|}{ Gypsum Brick } & \\
\hline & & $10 \%$ & $20 \%$ & $30 \%$ & $40 \%$ & $50 \%$ & \\
\hline $\mathrm{Cu}$ & 0.0137 & 0.0011 & 0.0029 & 0.0123 & 0.0168 & 0.0173 & 100 \\
\hline $\mathrm{Fe}$ & 4.3290 & 3.1350 & 3.6169 & 3.6689 & 3.8348 & 3.8585 & NA \\
\hline $\mathrm{Al}$ & 0.7670 & 0.8110 & 1.4706 & 1.6990 & 1.8863 & 1.9160 & NA \\
\hline $\mathrm{Pb}$ & 0.0271 & 0.0019 & 0.0025 & 0.0032 & 0.0041 & 0.0056 & 5 \\
\hline $\mathrm{Zn}$ & 0.3670 & 0.1270 & 0.1309 & 0.1415 & 0.1540 & 0.1705 & 500 \\
\hline $\mathrm{Ni}$ & 0.0024 & 0.0089 & 0.0092 & 0.0103 & 0.0166 & 0.0189 & 1.34 \\
\hline $\mathrm{Ba}$ & 0.2540 & 0.1040 & 0.3030 & 0.6520 & 0.7880 & 0.8810 & 100 \\
\hline $\mathrm{Cr}$ & 0.0113 & 0.0042 & 0.0058 & 0.0072 & 0.0114 & 0.0160 & 5 \\
\hline As & 0.0027 & 0.0065 & 0.0087 & 0.0095 & 0.0108 & 0.0174 & 5 \\
\hline $\mathrm{V}$ & 0.2060 & 0.2280 & 0.2930 & 0.3550 & 0.4260 & 0.6880 & NA \\
\hline $\mathrm{Be}$ & 0.0005 & 0.0002 & 0.0003 & 0.0034 & 0.0043 & 0.0056 & NA \\
\hline Se & 0.0027 & 0.0027 & 0.0035 & 0.0049 & 0.0057 & 0.0084 & NA \\
\hline $\mathrm{Ag}$ & 0.0027 & 0.0028 & 0.0022 & 0.0022 & 0.0028 & 0.0025 & NA \\
\hline $\mathrm{Cd}$ & 0.0011 & 0.0003 & 0.0002 & 0.0003 & 0.0007 & 0.0005 & 1 \\
\hline
\end{tabular}

NA stand for Not Applicable.

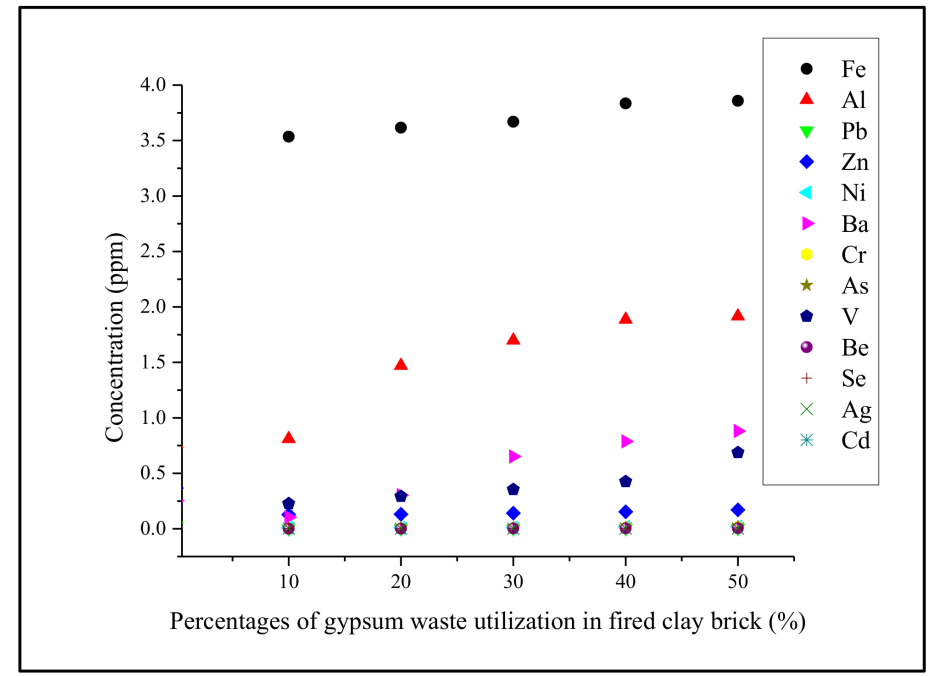

Figure 6. Effect of gypsum waste utilization on the leachate concentration of heavy metals in fired clay brick. 


\section{Conclusions}

From the study, the properties and leachability of fired clay bricks incorporated with gypsum waste were determined. Based on the results, the dry density and compressive strength of gypsum brick compatibly decreased when the amount of gypsum waste incorporation increased compared to the control brick. This happened as the utilization of gypsum waste in fired clay brick increased the quantity of pores and lowered the density of brick, which caused the fired clay brick to easily break. However, the gypsum brick with up to $20 \%$ still fulfilled the minimum requirement of the standard, but not for the 30, 40 and 50\% gypsum bricks. Meanwhile, the values of shrinkage and IRS were increased by increasing the amount of gypsum waste into the fired clay brick. Apparently, only up to $20 \%$ of the gypsum waste incorporation produced fired clay brick with fair properties as stated in the standard. Nevertheless, the best result was demonstrated by $10 \%$ of waste utilization with $47.5 \%$ of shrinkage, $1.37 \%$ of dry density, $22.87 \%$ of IRS and $28.3 \%$ of compressive strength shown by the adequate properties possessed.

The leachability test highlighted that the concentrations of the heavy metals were significantly reduced after the firing process. The findings from SPLP also showed that the concentrations of the heavy metals in all crushed samples manufactured did not exceed the regulatory limit specified by USEPA. This indicated that incorporating gypsum waste into fired clay brick could produce a new alternative disposal method for gypsum waste generated, which was highly recommended to be used as the building material. In a nutshell, this effort is an effective solution in enhancing the lifespan of the landfill and possibly reducing the pollution of the environment. Further investigation on the emissions released during the firing process of manufacturing the gypsum bricks shall be conducted in the subsequent study.

Author Contributions: Conceptualization, N.J.A.H. and N.N.H.H.; methodology, A.A.H., N.A.S.; software, N.J.A.H., A.A.K.; validation, A.A.K., P.P. (Paweł Pietrusiewicz), and N.J.A.H.; formal analysis, N.M.N., M.G., M.N., and A.A.H.; investigation, N.N.H.H., N.A.S., I.W., and A.A.N.; resources, A.A.K., P.P. (Paweł Pietrusiewicz), P.P. (Paweł Palutkiewicz), M.G., and B.J.; data curation, N.J.A.H., A.A.K., M.N., N.M.N., and A.A.H.; writing—original draft preparation, N.J.A.H., N.N.H.H. and A.A.K.; writing-review and editing, A.A.K., M.N., I.W., P.P. (Paweł Palutkiewicz) and B.J.; supervision, N.A.S.; funding acquisition, N.J.A.H., A.A.H. All authors have read and agreed to the published version of the manuscript.

Funding: This study was financially supported by Industry Grant, Universiti Tun Hussein Onn Malaysia (UTHM) via Vot No. M005.

Institutional Review Board Statement: Not applicable.

Informed Consent Statement: Not applicable.

Data Availability Statement: The data presented in this study are available on request from the corresponding author.

Acknowledgments: The authors would like to thank the Research Management Centre of Universiti Tun Hussein Onn Malaysia (UTHM) for the award of the postgraduate research grant (Vot No. H351). The authors would like to extend their gratitude to Department of Physics and Faculty of Mechanical Engineering and Computer Science, Częstochowa University of Technology, Częstochowa, Poland.

Conflicts of Interest: The authors declare no conflict of interest.

\section{References}

1. Halimah, H. Environmental Quality Report, Department of Environment Malaysia; Ministry of Natural Resources and Environment Malaysia: Putrajaya, Malaysia, 2014.

2. Adenan, S. Environmental Quality Report, Environmental Quality (Scheduled Wastes) Regulations; Ministry of Natural Resources and Environment: Putrajaya, Malaysia, 2005.

3. Raghavendra, T.; Udayashankar, B.C. Engineering properties of controlled low strength materials using fly ash and waste gypsum wall boards. Constr. Build. Mater. 2015, 101, 548-557. [CrossRef]

4. Guidotti, T.L. Hydrogen sulfide intoxication. Handb. Clin. Neuro. 2015, 131, 111-133. 
5. Jong, D.; Joss, M.; Schraven, S.; Zhan, D.; Weijnen, M. Sustainable smart resilient low carbon eco knowledge cities; making sense of a multitude of concepts promoting sustainable urbanization. J. Clean. Prod. 2015, 109, 25-38. [CrossRef]

6. Raco, M.; Street, E. Resilience planning, economic change and the politics of post-recession development in London and Hong Kong. Urban Plan 2012, 49, 1065-1087. [CrossRef]

7. Basnou, C.; Alvarez, E.; Bagaria, G.; Guardiola, M.; Isern, R.; Vicente, P.; Pino, J. Spatial patterns of land use changes across a mediterranean metropolitan landscape: Implications for biodiversity management. Environ. Manag. 2013, 52, 971-980. [CrossRef]

8. British Standard Institution. Method of Test for Soil for Civil Engineering Purposes-Part 2: Classification Tests. London: BS 1377:2. 1990. Available online: http:/ / www.standardsuk.com/ (accessed on 31 August 1990).

9. British Standard Institution. Methods of Test for Soils for Civil Engineering Purposes-Part 4: Compaction-Related Tests. London: BS 1377:4. 1990. Available online: http:/ / www.standardsuk.com/ (accessed on 31 August 1990).

10. Kadir, A.A.; Mohajerani, A.; Roddick, F.; Buckeridge, J. Density, Strength, Thermal Conductivity and Leachate Characteristics of Light-Weight Fired Clay Bricks Incorporating Cigarette Butts. World Acad. Sci. Eng. Technol. 2009, 53, $1035-1040$.

11. Kadir, A.A.; Hinta, H.; Sarani, N.A. The utilization of coffee waste into fired clay brick. ARPN J. Eng. Appl. Sci. 2015, 10, 6289-6292.

12. Victoria, A.N. Characterisation and performance evaluation of water works sludge as bricks material. Int. J. Eng. Appl. Sci. 2013, 3, 69-79.

13. Monteiro, S.N.; Alexandre, J.; Margem, J.I.; Sanchez, R.; Vieira, C.M.F. Incorporation of sludge waste from water treatment plant into red ceramic. Constr. Build. Mater. 2008, 22, 1281-1287. [CrossRef]

14. Cusido, J.A.; Cremades, L.V. Environmental effects of using clay bricks produced with sewage sludge: Leachability and toxicity studies. Waste Manag. 2012, 32, 1202-1208. [CrossRef]

15. BS EN 772-11, Methods of Test for Masonry Units Part 11: Determination of Water Absorption of Aggregate Concrete, Manufactured Stone and Natural Action and the Initial Rate of Water Absorption of Clay Masonry Units; BSI British Standards Institution: London, UK, 2011; pp. 1-12.

16. BS 12 3921, B.S.I British Standards Institution. British Standard Specification for Clay Bricks; BSI British Standards Institution: London, UK, 1985.

17. US EPA. Method 1312: Synthetic Precipitation Leaching Procedure (SPLP). In Test Methods for Evaluating Solid Waste: Physical/Chemical Methods; SW-846: Washington, WA, USA, 1994.

18. Goel, G.; Kalamdhad, A.S. An Investigation on use of paper mill sludge in brick manufacturing. Constr. Build. Mater. 2017, 148, 334-343. [CrossRef]

19. Ukwatta, A.; Mohajerani, A. Effect of organic content in biosolids on the properties of fired-clay bricks incorporated with biosolids. J. Mater. Civ. Eng. 2017, 29, 1-11. [CrossRef]

20. Seynou, M.; Millogo, Y.; Ouedraogo, R.; Traore, K.; Tirlocq, J. Firing transformations and properties of tiles from clay from Burkina Faso. Appl. Clay Sci. 2011, 51, 499-502. [CrossRef]

21. Tsozue, D.; Nzeugang, A.N.; Mache, J.R.; Loweh, S.; Fagel, N.; Nzeukou, A.; Richard, J.; Loweh, S.; Fagel, N. Mineralogical, physico-chemical and technological characterization of clays from Maroua (Far-North, Cameroon) for use in ceramic bricks production. J. Build. Eng. 2017, 11, 17-24. [CrossRef]

22. Smith, R.G.; Allal, M. Small Scale Brickmaking; International Labour Office: Geneve, Switzerland, 1984.

23. Sarani, N.A.; Kadir, A.A.; Rahim, A.S.; Mohajerani, A. Properties and environmental impact of the mosaic sludge incorporated into fired clay bricks. Constr. Build. Mater. 2018, 183, 300-310. [CrossRef]

24. Nwoye, C.I.; Obidiegwu, E.O.; Mbah, C.N. Production of bricks for building construction and predictability of its post-fired volume shrinkage based on apparent porosity and water absorption capacity. Res. Rev. J. Mater. Sci. 2014, 2, 17-26. [CrossRef]

25. Baskar, R.; Begum, K.M.M.S.; Sundaram, S. Characterization and reuse of textile effluent treatment plant waste sludge in clay bricks. J. Univ. Chem. Technol. Metall. 2006, 41, 473-478.

26. BIA. Technical Notes 3A-Brick Masonry Material Properties. Tech. Notes Brick Constr. Available online: https://www.gobrick. com (accessed on December 1992).

27. Karaman, S.; Ersahin, S.; Gunal, H. Firing temperature and firing time influence on mechanical and physical properties of clay bricks. J. Sci. Ind. Res. 2006, 65, 153-159.

28. Weng, C.H.; Lin, D.F.; Chiang, P.C. Utilization of sludge as brick materials. Adv. Environ. Res. 2003, 7, 679-685. [CrossRef]

29. Lin, K.L.; Huang, L.-S.; Shie, J.L.; Cheng, C.J.; Lee, C.H.; Chang, T.C. Elucidating the effects of solar panel waste glass substitution on the physical and mechanical characteristics of clay bricks. Environ. Technol. 2013, 34, 15-24. [CrossRef]

30. Ahmed, A.; Soliman, A.; Naggar, M.E.; Kamei, T. An assessment of geo-environmental properties for utilization of recycled gypsum in earthwork projects. Soils Found 2015, 55, 1139-1147. [CrossRef]

31. Kizinievic, O.; Kizinievic, V.; Pundiene, I.; Molotokas, D. Eco-friendly fired clay brick manufactured with agricultural solid waste. Arch. Civ. Mech. Eng. 2018, 18, 1156-1165. [CrossRef]

32. British Standard Institution. Specification for Masonry Units Part 1: Clay Masonry Units. London. BS EN 771:1. 2015. Available online: http:/ / www.standardsuk.com/ (accessed on 31 October 2011).

33. Ukwatta, A.; Mohajerani, A.; Eshtiaghi, N.; Setunge, S. Variation in physical and mechanical properties of fired-clay bricks incorporating ETP biosolids. J. Clean. Prod. 2016, 119, 76-85. [CrossRef] 
34. Kadir, A.A.; Sarani, N.A.; Zaman, N.N.; Abdullah, M.M.A.B. Feasibility study on utilization of palm fibre waste into fired clay brick. AIP Conf. Proc. 2017, 1835, 20-39.

35. Krishnan, P.; Jewaratnam, J.; Jewaratnam, J. Recovery of water treatment residue into clay bricks. Chem. Eng. Trans. 2017, 56, 1837-1842.

36. Kadir, A. A.; Sarani, N. A. Utilization of Palm Oil Fuel Ash in Brick Manufacturing for Lightweight Fired Clay Brick Production. Int. J. Sust. Constr. Eng. Technol. 2020, 11, 136-150.

37. Kazmi, S.M.; Abbas, S.; Saleem, M.A.; Munir, M.J.; Khitab, A. Manufacturing of sustainable clay bricks: Utilization of waste sugarcane bagasse and rice husk ashes. Constr. Build. Mater. 2016, 120, 29-41. [CrossRef]

38. Punmia, B.C.; Jain, A.K.; Jain, A.K. Basic Civil Engineering; Laxmi Publications Pvt Limited: Chennai, India, 2003.

39. Lin, D.F.; Weng, C.H. Use of sewage sludge ash as brick material. J. Environ. Eng. 2001, 127. [CrossRef]

40. Taha, Y.; Benzaazoua, M.; Hakkou, R.; Mansori, M. Natural clay substitution by calamine processing wastes to manufacture fired bricks. J. Clean. Prod. 2016, 135, 847-858. [CrossRef]

41. Jahagirdar, S.S.; Shrihari, S.; Manu, B. Utilization of textile mill sludge in burnt clay bricks. J. Environ. Prot. $2013,3,6$. 